\title{
Scientific Knowledge of Peatland Use and Risks and Media: Study of Peatland Information in Online Media in Indonesia
}

\author{
S. Rouli Manalu ${ }^{1}$, Laila Kholid Alfirdaus ${ }^{2}$, Hendra Try Ardianto ${ }^{3}$, Kushadajani $^{4}$ \\ \{srmanalu@live.undip.ac.id ${ }^{1}$ \} \\ Universitas Diponegoro, Indonesia ${ }^{1,2,3,4}$
}

\begin{abstract}
This research examines the ways in which the scientific knowledges about peatland or wetland are communicated to public through mass media in Indonesia. Indonesia is one of the countries with extensive tropical peatland areas with over 15 million ha of peatlands that makes up over $12 \%$ of its forest. The information about peatland often comes forward to public attention and to public discourse in relation to forest fire and tick haze resulted from the fire. However, there is not much scientific explanation could be found regarding the characteristics of this type of land and why its so vulnerable to forest fire in the news. Furthermore, not many news media outlets mention the risks of opening and clearing peatland area for industrial purpose, and the consequences it brought to ecosystem and to global climate. This research is interested to understand how the scientific knowledge regarding the peatland and peatland uses as well the consequences of the use are communicated to the public in national media in Indonesia. Content analysis is conducted to the corpus of media reports in 2018 and 2019. This research argues investigating mass media presentation regarding the scientific knowledge of peatland will help us better understand the public understanding about the risks and the consequences of peatland use.
\end{abstract}

Keywords: Peatland, Scientific Knowledge, Media Content, Public Communication.

\section{Introduction}

The news of forest and land fire is one of the main topics in many of mass media in Indonesia in the year of 2019. Not only this year alone, however, the news is a reoccurring theme that has repeatedly appeared in the forefront of national news in the country in the years before. Information regarding tick haze, hotspots of fire, acreages of burned land, respiratory problems and health effects of forest fire, and the endeavors to overcome fire can be found in the content of large number of national mass media, both online and offline. This repeated forest and land fire in Indonesia has specific characteristic, which not the same with fire in other different countries -such as bush fire in Australia- because the burned area is located in the tropical peatland or wetland.

Indonesia is one of the countries with extensive tropical peatland areas with over 15 million ha of peatlands that makes up over $12 \%$ of its forest [1]. This type of land largely located in the East Coast of Sumatera, part of Kalimantan, Sulawesi, and Papua, with Sumatera has $34 \%-43 \%$ of the total Indonesian peatland, Kalimantan has $28--32 \%$, and Papua has $25 \%-38 \%$ [2]. Peatland is a type of soil that is formed by the accumulation of organic 
matters, such as the residue of plants, which took place in a long period of time. Formally, regulation in Indonesia defined peatland as "a naturally occurring organic material of plant residues that decomposes imperfectly and accumulates in swamps", as can be read in the Government Regulation (GR) No. 71 of 2014 that has been amended by GR No. 57 of 2016 on the Protection and Management of Peat Ecosystem [1].

Indonesian government has taken a number of measures in managing peatland and in preventing disastrous events, including the establishment of Peatland Restoration Agency (Badan Restorasi Gambut - BRG) [1]. This agency has mission to restore peatland in the country by using $3 \mathrm{R}$ method, which consist of: Rewetting the areas that have been impacted by the drainage process for cultivation; Revegetation and bring back the natural plants life and floras that are native to peatland; and Revitalization and bring back the livelihood and symbiotic ecosystem of peatland [3]. Although there are debates and discussions regarding the effectiveness and efficacies of this agency in doing its jobs, particularly in facing industrial and economic demand of peatland use, the mission in restoring the peatland is a positive step forward in managing peatland use.

However, other than restoring peat hydrological area itself, public knowledge of peatland use and risk also need to be managed properly. This is because the use of peatland would affect not only the land, the biodiversity, the industrial players, and the livelihood of local communities, but it is also having serious consequences to the wider population in far distance of the area (even across nations), in the case of haze cause by burned forest. The peatland use is even more pertinent to global community because of the carbon emission and climate change. Public must be educated with scientific facts and scientific knowledge of peatland use and the possible risks that could come from it. Better public knowledge regarding this matter will bring greater accountability in managing peatland by the local and national government, and would further lead to deliberative approach in environmental governance. This research, therefore, aims to examine the ways in which public are informed regarding the knowledge and scientific fact of peatland through national mass media in Indonesia, since mass media could also function as an important conduit in educating public. The subsequent section would explain some scientific facts about peatland that would bring public better understanding about peatland.

\section{Literature Review}

\subsection{Scientific Knowledge of Peatland}

Scientific understanding about peatland has been accumulated from many researchers conducted to discern many characteristics of it. There are three characteristics that would be discussed in this article; the characteristic of soil composition and the ability to store carbon, the characteristic of biodiversity, and the susceptibility to subsidence.

The specific soil compositions and characteristics of peatland renders its significance in maintaining global carbon emissions. In an unutilized condition, tropical peatland such as found in Indonesia hold extremely large amount of carbon in its soil and biomass [4]. According to Hergoualc'h and Verchot [4], Indonesian peat swamp forests store $220 \pm 28$ tons of carbon per hectare ( $\mathrm{t} \mathrm{C} / \mathrm{ha}$ ) in the Phyto mass (alive and dead vegetation) on average, and $668 \pm 20 \mathrm{t} \mathrm{C} /$ ha per meter depth of peat. Carbon in peatland regularly found in the soil, and in a shallow 1-meter-deep peatland forest, the ratio is 3:1 between soil and phytomass, whereas 
in vegetation, $80 \%$ of the carbon stored in trees [4]. Although methods for estimating precisely carbon storage in peat swam forest are continuously developed [4], from the previous available data we can see the consequential role of peatland in holding the amount of carbon, and that managing the peatland properly will also contributing in reducing the global carbon emission.

Not only in regard to carbon storage and carbon emission, peatland also important in providing ecosystem to numerous species, in which Sumatera and Kalimantan peatland are part of biodiversity hotspot [5]. MacKinnon et al, in their book estimated that Kalimantan is the home to up to fifteen thousand species of flower plants, and 37 endemic birds as well as 44 endemic mammal species [3]. Other notable contributions of peatland to ecosystem are to preserve air and water quality of the surrounding area, and in many regions, peatland is as source of protein for local consumption that come from the fish population [3].

Indonesian tropical peatland clearing, however, continuously increasing by year, where it is mostly functioned as the main area for monoculture palm oil plantations as well as area for providing wood for pulp industry. Research from Gaveau et al [6], mentioned the increasing of industrial plantation in Kalimantan is as high as $6.2 \mathrm{Mha}$, or counted for $170 \%$, from 2000 to 2017 , and $88 \%$, or 3.06 Mha of the area are attributed to palm oil expansion. To use peatland for industrial plants, such as palm oil and wood pulp plantation, means that the area must be first cleared from its natural vegetations and then drain the soil from its water content. With the peatland carbon storage mainly in its soil and its vegetation, clearing the area for industrial plants will cause the carbon to be released to the atmosphere, which will contribute to a massive global carbon emission [7]. As we know, global carbon emission is the heart of the global climate change debate that has taken place today. Not only this, draining the peatland together with carbon oxidation will also resulting in land subsidence [7][8]. Measuring subsidence in several locations in Riau and Jambi, research from Hooijer et al indicate that subsidence rate of drainage peatland could reach around $1.5 \mathrm{~m}$ over the first five year after drainage, and will typically amount to $2.5 \mathrm{~m}$ in the period of 25 years [8]. In a long term, peatland subsidence will lead to the loss of agricultural productions and the loss of biodiversity in the peatland area.

The conversion of peatland to industrial plantation is even worse when the method for clearing is done through burning the area. This often the case in peatland clearing in Indonesia, as burning is seen as the most cost-effective method [7]. The burning method in numerous occasions is the cause of the vast forest and land fire, such as that took place in 2015. It is mentioned the forrest fire in that particular year reached up to 26,100 square kilometers $(10,100$ square miles) of land, with daily carbon dioxide emission exceed those from all the US economic and industrial activities [7].

\subsection{Public Knowledge of Environment}

Educating public regarding environment could not be more urgent today, as we experience more environmental degradation cause by human activities, such as land and ocean waste, land clearing, industrialization, etc. We also see some extreme environmental phenomena that unprecedented in the forms of flood, forest fire, longer drought, extreme heat of summer, harsh winter, and many more. However, knowledge about environment often come in the form of scientific knowledge with highly technical language. This form of information could not be easily accessible to public. In order to make it more accessible, it should be delivered in language that non-expert could understood. For this purpose, mass media could help and provide significant service. 
Mass media coverage of science could come in the form that accessible to non-expert, or in popular science form. In 1935, Fleck in his book has defined popular science as "science for non-experts, in which knowledge, as it moves from esoteric to exoteric circles, becomes simplified, lucid, apodictic, and absolutely certain" [9]. Hence media report on science, including environmental science, can be an important form of information to be used for public education to create well informed public regarding the impact of human activities to environmental conditions.

Although it has been argued that media reports at times communicate uncertainty when the science result is not a clear cut argument [9], but oftentimes media interventions are able to improve public understanding of the dynamic and the complexity of human-environment interactions [10]. This media intervention can be seen in the case of climate change, as Luedecke and Boykoff [10] mention in their writing. And even though media at times rely more on the authoritative and official sources, and therefore informed by authority-order bias Luedecke \& Boykoff [10], media coverages could also signals "key frames" in the complex relationships between scientists, policy actors, and general public [11].

Considering the affordances and the potential roles of mass media in delivering more indepth information and knowledge and scientific facts of environment conditions, this research aims to examine whether mass media also do the same with peatland use and its risks, particularly in the case of tropical peatland in Indonesia. This research will investigate the ways in which media in Indonesia convey information related to peatland through their news report for public information consumption.

\section{Data and Method}

To investigate the matter, this research collecting data from three (3) online national media reports on peatland, and various related issues to peatland, in the past two years (2018 and 2019). The media contents included in the analysis were those from kompas,com, tempo.co, and jawapos.com Although there is general perception in the country that many online media contents do not have the same quality with the older versions, such as paper and magazine (particularly in the case of Harian Kompas with kompas.com and Majalah Tempo and tempo.co), but this research argues that media contents in the online platform has its own advantages in reaching more readers, and thus have high accessibility as compare to the older platforms.

The news to be analyzed are in Indonesian, and they were collected by using search engine by using keywords "gambut", "lahan gambut", "rawa gambut". All news entry has the keyword were then included in the data corpus. Using this method, this research managed to build data corpus as seen in the table 1 .

Table 1. The number of news analyzed according to the name of the media and the year of publishing

\begin{tabular}{cccc}
\hline \multirow{2}{*}{ No. } & \multirow{2}{*}{ Media Name } & \multicolumn{2}{c}{ Year } \\
\cline { 3 - 4 } & & 2018 & 2019 \\
\hline 1 & jawapos.kom & 18 & 20 \\
2 & tempo.co & 24 & 24 \\
3 & kompas.com & 17 & 20 \\
& Total & 59 & 64 \\
\hline
\end{tabular}


The total number of news analyzed in this research are 123 news entries, with the composition of name of media, and years, as seen in the table. In each year, the time of the news entries were run from January to December, from each media platform.

All news entries in data corpus are then analyzed by applying a number of predetermined codes that need to be identified in the news. This research determined two coding themes; (1) the general theme or main information in the news; (2) the news sources interviewed in the news. These codes were used to determine the point of views in the news, and the authoritative sources quoted in the news. The coding process was also conducted in Indonesia, but the result of the coding was then translated to English. Quantitative and qualitative analysis were used in further data analysis. Quantitative analysis was used to see the pattern of information media content, and qualitative analysis was used to look for connections among different patterns of information and to make sense those connections to build arguments. The result of the analysis will be explained in the subsequent section.

\section{Findings and Discussion}

\subsection{The Themes of the News}

From all news entries analyzed in this research $(\mathrm{N}=123)$, the themes of the news in each media platform are categorized by using seven codes, as shown in Figure 1.

\section{The Themes of the News}

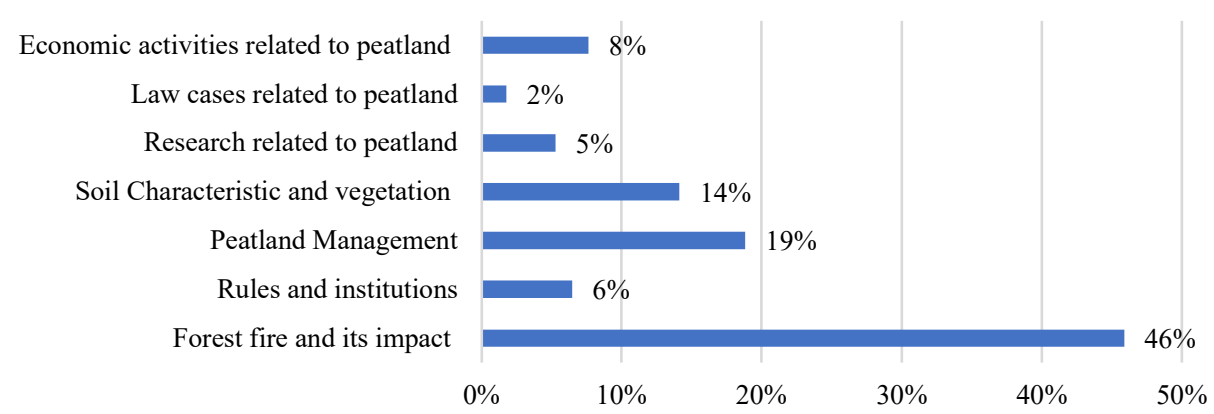

Fig. 1. The news entries related to peatland in all media platform.

Data analysis revealed that information about forest fire, numerous endeavors to overcome the fire, and the impacts of the fire dominated the news about peatland. Data analysis shows the news about the fire can be found in the contents of all media platforms, both in 2018 and 2019. The type of the news is usually hard news report that contain $5 \mathrm{~W}+1 \mathrm{H}$ elements regarding the event of peatland fire. The fact that this forest fire news appeared in each year could indicates that burned peatland most likely took place yearly, with only different intensity from one year to another. The location of the forest fire spread across Sumatera and Kalimantan, with Riau and West Kalimantan as the two provinces with the forest fire reports. The news in this theme also mention numerous government agencies that were involved in the efforts to overcome the fire, such as Regional Peat Restoration Team (Tim Restorasi Gambut Daerah/TRGD), Regional Disaster Management Agency (Badan 
Penanggulangan Bencana Daerah/BPBD), Manggala Agni, Meteorology Climatology and Geophysics Agency (Badan Meterology, Klimatologi, dan Geofisika/BMKG), Police forces, and local governments where the fire happened. Following the principles of hard news reporting, most often than not the statements of the spokesperson of those agencies are quoted in the news, most likely in attempt to add more authority to the news.

The second most frequent news that appear from data analysis is news about peatland management. The news entries in this theme, among others, describe the approach in protecting and restoring damaged peatland, including the utilization of $3 \mathrm{R}$ method (rewetting, revegetation, and revitalization) from BRG and description of government design for peatland protection. Some other news in with this theme depict several international cooperation that Indonesian government has engaged with in governing peatland use, and community and stakeholder's engagement for peatland protection. Similar with the news entries about forest and land fire, most of the news about peatland management are also in the form of reporting of events or activities that utilize $5 \mathrm{~W}+1 \mathrm{H}$ approach. Furthermore, if we look closely, the talk of peatland management in many online news are not specifically about comprehensive analysis or in-depth writing piece about peatland management. On the contrary, it is solely journalistic report of some particular events that happen to relate to peatland management.

Further, the third most frequent news that appear in online media platforms is the news that talk about soil and vegetations in peatland area. The news in this category inform readers about the peatland soil compositions that naturally have high water level, and how it can hold a large amount of carbon that can easily flammable if it is drained or reduced from its natural water level. The news in this group also contain information about the distinctive natural vegetations of the peatland. Natural vegetation means the native plants that have peat swamp as their natural habitat, and that can live in the pristine peat swamp without any treatment and soil alteration. The news entries that talk about this natural vegetation in many occasions is used to contrast the native plants to the industrial plants, such as palm oil and acacia. These industrial plants need drainage peat areas to be able to survive. Hence, the news that contain information about natural vegetations can provide knowledge to readers that there is somewhat unnaturalness in clearing the peatland from its native plants, and this intervention would have a number of repercussions, including the risk of burned peatland that release carbon dioxide to the atmosphere.

In relation to the scientific knowledge about peatland, the news in the third group are the ones that can be identified as closest to scientific knowledge about peatland. Geological information about the land, and biological knowledge about the natural plants with peat swamp as habitat allow public to know more about the distinct characteristic of peatland that need to be cautiously considered in opening and clearing the land for industrial purpose. Nevertheless, although this information can be found in the news, it only appears in small percentage. The information seems only perfunctory with only superficial explanation and without deep analysis and thorough commentaries. Thus, this research argues the existing news contents are still insufficient, and more detail facts and information need to be supplemented in order to reach the objective of educating public regarding peatland

Other themes yielded from the analysis only surfaced in smaller percentage, with the news about economic activities related to peatland counted for $8 \%$ of the news, and the news that talk about rules and government agencies in governing peatland appear only in $6 \%$ of the news. It is worth mentioning that there are some news entries about research on peatland, even only in small percentage. However, the contents of these news are not describing the content or the substance of the research, or the problem of the peatland that has been research. Instead, this news only mentions the cooperation in research conducted by the government with other 
countries and other international agencies, or the event that brought a number of international researchers that come to Indonesia. Even if the content of research is mentioned in the news entries, it is only in brief format, with not much explication in the news. This result further substantiates the argument there is not much of scientific facts and knowledge about peatland communicated through online news to be able to educate the public about peatland.

\subsection{The sources quoted in the news}

The next category of analysis on the corpus of data is the sources of information quoted in the news. Through this analysis, this research can discern individuals or organizations who are valued by the journalists as authoritative voice to provide information to the public. This research can also determine the perspective that is favored and the aspect that is emphasized by the journalists and the media itself. From this information, it can be determined whether a particular news has provided information that facilitate public to gain more scientific knowledge about peatland.

\section{The sources quoted in the news}

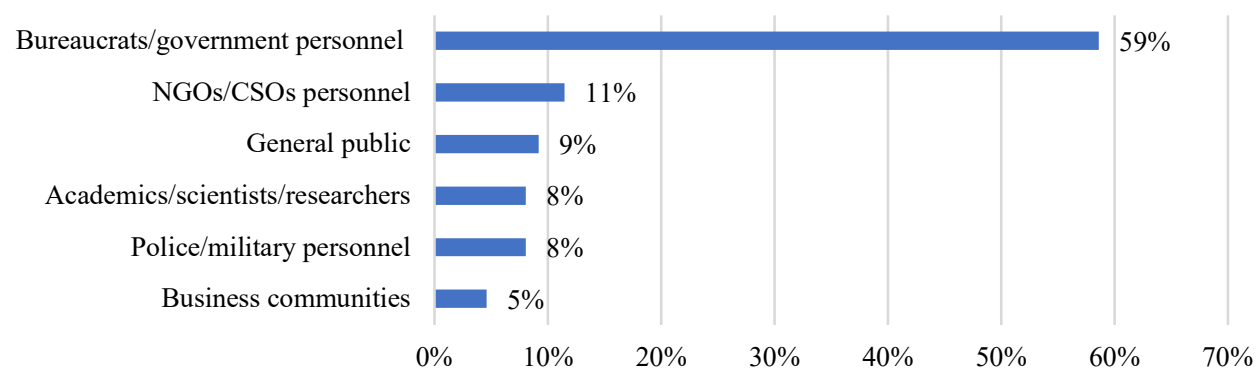

Fig. 2. The categories of the sources quoted in the news in all media platform.

Analysis on news entries shows that large number of quoted statements in the news are come from government officials in various ranks and positions, from the highest office of presidency to the leaderships in the village level. Some the most quoted statements are come from the spokespersons of the Ministry of Environmental and Forestry (Kementerian Lingkungan Hidup dan Kehutanan/KLHK), the spokespersons of Peatland Restoration Agency (BRG), the spokespersons of Regional Disaster Management Agency (BPBD), and the spokespersons of Regional Peat Restoration Team (TRGD). Since a large number of news are the reports of forest fire or burned peatland, the relevant agencies who are responsible for overcoming the fire become the main resources of information sought by the journalists. Peatland Restoration Agency (BRG) also become organization to go to when writing about peatland. The high number of government officials' statements in the news is an indication of the high reliance of the journalists and media organizations to the official agencies to acquire information, and therefore bring to domination of the perspective and the voice of government in portraying peatland information to the public.

The perspectives and the voices of NGOs or CSOs could be alternative to balance the domination of government perspective. However, the number of news that bring forward statements from NGOs in the news are smaller significantly compare to the quoted statement from the government officials. Some of the NGOs mentioned in the news are: Greenpeace Indonesia, United Nations Environmental Program (UNEP), WALHI, Yayasan Palung, 
Wetland International Indonesia, Yayasan Ekosistem Lestari, Yayasan Madani Berkelanjutan, Sawit Watch, JATAM, and International Animal Rescue. In many occasions, NGOs are posing questions or bring forward opposing arguments to the statements or information made by government officials. For example, there is news in tempo.co (23 Oct 2018) when Director of Wetland International Indonesia stated his skepticism that the national government under Joko Widodo administration would keep its commitments and policies in governing land and forest in the second term of administration since, according to him, the details and specific targets regarding land, forest, and peatland are missing in Nawacita II. Another example is the news in jawapos.com (24 Oct 2018) when JATAM Coordinator was quoted in his insistence to the government to evaluate peatland clearing for agriculture and industrial plants. He emphasized that it would raise a number of risks to peatland and the biodiversity surround it. It can be seen that different sides of argument regarding peatland brought by NGOs. Nevertheless, the NGOs perspectives and voices brought to the news do not presenting so much about scientific facts and knowledge about peatland. There are talks about protecting peatland from more land clearing, protecting native species and biodiversity of peatland, demanding the right of local communities for fresh air, urging proper penalty for land concession holders where the peatland fire started, etc.; all of these talks can be good counterbalance to the voices of the government officials, but not necessarily provide information to educate public regarding scientific knowledge of peatland.

Other sources quoted in the news in a smaller proportion are general public, academics/ scientists/ researchers, police/military personnel, and business community. The category of general public surfaced in the news as students, farmers, and community members near the peatland area. They were interviewed in the context of asking how forest fires and haze was affecting their activities and their daily routines. What is interesting and highly relevant to this research is the voices of the scientists that also appear in the news. Some of the scientists/academics that quoted in the news are scientist from Gajah Mada University (UGM), Japan Peatland Society (JPS), Columbia University, International Peat Mapping, Bogor Agricultural Institute (IPB), Bandung Institute of Technology (ITB). However, not all of these scientists are quoted based on their works or their research. Most of the time they are interviewed just to give commentaries or responses in regards to current events about peatland. Even one of the scientists from IPB was quoted in regards to the legal case that involved disputes between business organizations. In other words, although there are times scientists or researchers are asked to be sources in the news, but they are not necessarily asked to explain the substance of scientific works that they are conducted, more frequently they are just asked for opinion about current affair related to peatland instead. It does not mean that their opinions/commentaries do not have scientific information, it is just the proportion of those information in the news only occupy small section of the news, and do not portray a more comprehensive information.

To sum up, the two-parts analysis conducted in this research shows little evidence that scientific facts, scientific knowledge, and scientific research of peatland has been the main part of the online news contents. The scientific fact of peatland indeed at times appear in the news, but it is only occupying small proportion of the news, which mainly in the form of short descriptions and expert commentaries and opinions to supplement other information in the news. The analysis also reveals that the form of the news writings most of the time is in the reporting format, which take hard-news writing approach of events or activities related to peatland. Meanwhile, coverage in the form of in-depth writing that contain scientific facts regarding peatland, such as biodiversity in peatland areas, carbon storage and the risk of carbon emission in peatland, the risk of land subsidence, among others, are rarely appear news 
article. The articles that are devoted to discuss research about the impacts of peatland use is also scarce to almost non-existence.

Hence, this research draws conclusion that online news regarding peatland in Indonesia have not taken the role to educate public regarding the scientific knowledge about peatland, and to inform public regarding the scientific fact and the risk of using and converting peatland for agricultural and industrial purposes. Referring the Fleck definition of popular science, the contents of online news have not shown its content as popular science, or science for nonexpert, to describe esoteric knowledge to large public in the form that is simplified, lucid, and certain. The research further argues the lack of public knowledge about environment and knowledge about the risks of human activities to the environment, including peatland, would lessen the public accountability of environmental governing and would further weaken the emergence of the deliberative process in environmental governing.

\section{Conclusion}

This research found that the contents of online media in Indonesia have not been able to educate public with scientific facts and knowledge of peatland, and the risk of converting peatland from its natural habitat since there not sufficient evident that show the particular information is appeared in the news contents. Indeed, there is some scientific facts regarding peatland in small number of the news, but it only occupies the small proportion and in the form of events reporting and expert commentaries and opinions. Mass media potentially have significant role for educating public to strengthen public accountability of and encourage deliberative process in environmental governing, however this has not been the case in the reality of online media contents in Indonesia.

\section{References}

[1] MoEF, "Managing peatlands to cope with climate change: Indonesia's experience," UNEP - UN Environment Programme. [Online]. Available: http://www.unenvironment.org/resources/ publica. [Accessed: 12-Apr-2018].

[2] M. Warren, K. Hergoualc'h, J. B. Kauffman, D. Murdiyarso, and R. Kolka, "An appraisal of Indonesia's immense peat carbon stock using national peatland maps: uncertainties and potential losses from conversion," Carbon Balance Manag., vol. 12, no. 1, p. 12, 2017.

[3] M. E. Harrison et al., "Tropical forest and peatland conservation in Indonesia: Challenges and directions," People Nat., 2019.

[4] K. Hergoualc'h, R. Carmenta, S. Atmadja, C. Martius, D. Murdiyarso, and H. Purnomo, "Managing peatlands in Indonesia: challenges and opportunities for local and global communities.," CIFOR Infobr., no. 205, 2018.

[5] N. Myers, R. A. Mittermeier, C. G. Mittermeier, G. A. B. Da Fonseca, and J. Kent, "Biodiversity hotspots for conservation priorities," Nature, vol. 403, no. 6772, p. 853, 2000.

[6] D. L. A. Gaveau, B. Locatelli, M. A. Salim, H. Yaen, P. Pacheco, and D. Sheil, "Rise and fall of forest loss and industrial plantations in Borneo (2000-2017)," Conserv. Lett., vol. 12, no. 3, p. e12622, 2019.

[7] H. N. Jong, “'Dangerous' new regulation puts Indonesia's carbon-rich peatlands at risk," Mongabay Environmental News. [Online]. Available: https://news.mongabay.com/2019/07/ dangerous-new-regulation-puts-indonesias-carbon-rich-peatlands-at-risk.

[8] A. Hooijer et al., "Subsidence and carbon loss in drained tropical peatlands: reducing 
uncertainty and implications for CO 2 emission reduction options.," Biogeosciences Discuss., vol. 8 , no. $5,2011$.

[9] L. Guenther and G. Ruhrmann, "Scientific evidence and mass media: Investigating the journalistic intention to represent scientific uncertainty," Public Underst. Sci., vol. 25, no. 8, pp. 927-943, 2016.

[10] G. Luedecke and M. T. Boykoff, "Environment and the media," Int. Encycl. Geogr. People, Earth, Environ. Technol. People, Earth, Environ. Technol., pp. 1-8, 2016.

[11] C. Trumbo, "Constructing climate change: claims and frames in US news coverage of an environmental issue," Public Underst. Sci., vol. 5, no. 3, pp. 269-284, 1996. 